\title{
PIRAMIDY EGIPSKIE - GROBY FARAONÓW CZY SPICHLERZE JÓZEFA
}

\section{THE EGYPTIAN PYRAMIDS - PHARAOH'S TOMBS OR JOSEPH'S GRANARIES}

\author{
Hieronim Kaczmarek \\ Katedra Turystyki, Wydział Nauk o Ziemi, Uniwersytet Szczeciński \\ ul. Mickiewicza 18, 70-383 Szczecin, Poland
}

ABSTRACT. This article is an attempt to take a new look at the research on the Egyptian pyramids conducted until the end of the nineteenth century in Poland.

Pytanie takie jak postawione w tytule pojawiło się przed badaczami już u schyłku starożytności. $\mathrm{W}$ różnych wariantach stawiają je i dzisiaj niektórzy autorzy publikacji, nierozumiejący cywilizacji starożytnych Egipcjan i niechcący przyjąc do wiadomości ustaleń egiptologów. Egipskie piramidy - budowle od starożytności budzące podziw myślą techniczną i swym ogromem, już w antyku stały się przedmiotem licznych studiów ${ }^{1}$. W epoce hellenistycznej Grecy zaliczyli je do siedmiu cudów świata ${ }^{2}$. Opanowały fantazję i myśl ludzką na tyle, że przez kilka tysiącleci, jakie upłynęły od wybudowania pierwszej z nich, powstała bogata literatura im poświęcona. Także dzisiaj wielu uczonych na nich skupia swe zainteresowanie ${ }^{3}$. Wznoszone były przez władców od

\footnotetext{
${ }^{1} \mathrm{O}$ wczesnych poglądach na temat celu budowy piramid zob. Stadelmann 1997, s. 264-284; Hornung 1999, s. 161-177.

${ }^{2}$ Starożytni do cudów świata zaliczali dzieła geniuszu ludzkiego, takie jak budowle (piramida Cheopsa w Gizie, wiszące ogrody Semiramidy w Babilonie, świątynię Artemidy w Efezie, Mauzoleum w Halikarnasie, Brama Isztar w Babilonie później zastąpiona przez latarnię morską w Faros) i arcydzieła sztuki (posąg Zeusa w Olimpii, Kolos Rodyjski; tu dodawano też Kolosy Memnona, a nawet posąg Asklepiosa w Epidauros, dzieło Trasymedesa z Paros). Za najwcześniejszy wykaz tych cudów uważa się dzisiaj listę stworzoną przez greckiego poetę, Antypatera z Sydonu w II w. p.n.e. Lista oparta na greckich opowieściach podróżniczych przytacza tylko te obiekty, do których Grecy dotarli i chętnie zwiedzali (Ro merowie 1997).

${ }^{3}$ Z nowszych opracowań historii piramid warto wymienić Stadelmanna 1997, a w języku polskim Edwardsa 1995 .
} 
Starego Państwa aż po początek Nowego ${ }^{4}$ na cmentarzyskach wokół Memfis (Giza ${ }^{5}$, Sakkara $^{6}$, Dahszur $^{7}$, Abu Roasz ${ }^{8}$, Zawijet el-Arian ${ }^{9}$, Abusir $^{10}$, Medum $^{11}$ ) i leżącej na północy Górnego Egiptu Icz-taui, stolicy z epoki Średniego Państwa (Liszt ${ }^{12}$, Lahun ${ }^{13}$, Hawara $^{14}$, Mazghuna ${ }^{15}$ ). W okresie Nowego Państwa znalazły też nielicznych naśladowców prywatnych na cmentarzysku w $\mathrm{Abydos}^{16}$ oraz na należącym do robotników (budowniczych grobów królewskich w Dolinie Królów ${ }^{17}$ ) cmentarzysku przy dzisiejszej miejscowości Deir el-Medina w Tebach Zachodnich. Później zwyczaj wznoszenia piramid jako grobowców królewskich pojawił się i na innych obszarach świata starożytnego - np. piramidy władców nubijskich w okolicach Meroe ${ }^{18}$. W Rzymie stanęła piramida pretora Gajusza Cestiusza przy Bramie Ostyjskiej (Porta Ostiensis) ${ }^{19}$. Do kształtów tych

\footnotetext{
${ }^{4}$ Za najstarszą uchodzi wzniesiona w Sakkarze piramida Dżosera (2690-2670 p.n.e.), a ostatnią znaną piramidę wzniósł twórca XVIII dynastii faraon Jahmes (1550-1525 p.n.e.) w Abydos. Daty odnoszące się do władców starożytnego Egiptu zaczerpnięte zostały z publikacji B eckeratha 1997.

${ }^{5}$ To trzy największe piramidy wzniesione przez Cheopsa (ok. 2604-2581 p.n.e), Chefrena (ok. 25722546 p.n.e.) i Mykerinosa (2539-2511 p.n.e.), władców IV dynastii uważane już przez starożytnych za jeden z cudów świata

${ }^{6} \mathrm{Z}$ najstarszą piramidą egipską wzniesioną przez Dżosera oraz piramidy Sechemcheta (2670-2663 p.n.e.), Userkafa (2504-2494 p.n.e.), Unisa (2367-2347 p.n.e.), Teti (2347-2337 p.n.e.), Pepi I (2335-2285 p.n.e.), Merenre (2285-2279 p.n.e.), Pepi II (2279-2219 p.n.e.), Ibi (38 władca XIII dynastii, którego trudno umiejscowić w czasie) i Chendżer (1753-1747 p.n.e.), także władca z XIII dynastii.

${ }^{7}$ Z piramidami Snofru (2639-2604 p.n.e.), Amenemhata II (1914-1879/76 p.n.e.), Senusereta III (18721853/52 p.n.e.) i Amenemhata III (1853-1806/05 p.n.e.) Ameni Kemau z początków XIII dynastii.

${ }^{8} \mathrm{Z}$ piramidą Dżedefre (2581-2572 p.n.e.)

${ }^{9} \mathrm{Z}$ piramidami Chaba (władca III dynastii), Nebka (2707-2690 p.n.e.).

${ }^{10} \mathrm{Z}$ piramidami Sahure (2496-2483 p.n.e.), Neferirkare (2483-2463 p.n.e.), Neferefre (2456-2445 p.n.e.), Niuserre (2445-2414 p.n.e.).

${ }^{11} \mathrm{Z}$ piramidą Snofru (2639-2604 p.n.e.).

${ }^{12}$ Z piramidami Amenemhata I (1976-1947 p.n.e.) i Senusereta I (1956-1911/10 p.n.e.).

${ }^{13} \mathrm{Z}$ piramidą Senusereta II (1872-1853/52 p.n.e.).

${ }^{14} \mathrm{Z}$ piramidą Amenemhata III (1853-1806/05 p.n.e.).

${ }^{15}$ Z piramidami Sebekneferu (1798/97-1794/93 p.n.e., Amenemhata IV (1807/06-1798/97 p.n.e.).

${ }^{16}$ Piramidki ceglane (o wys. 6 m) odkryte w 1858 r. przez Augusta Mariette’a do niedawna były datowane na okres Średniego Państwa.

${ }^{17}$ Grobowce o rozbudowanej formie, z piramidką jako jednym z elementów datowane są na czasy XVIIIXX dynastii, czyli na lata 1550-1070/1069 p.n.e. Groby podobnego typu w tym okresie wznoszono na przestrzeni aż do Aniby w Nubii, czyli ok. $200 \mathrm{~km}$ na południe od Asuanu.

${ }^{18}$ Królowie Napaty XXV dynastii budowali piramidy w el-Kuru (Pije (ok. 746-715/713 p.n.e.), Szabaka (715/713-700/698 p.n.e.), Szabataka (700/698-690 p.n.e.), w Nuri (Taharka (690-664 p.n.e.), Tanutamon (664-ok. 655 p.n.e.), Soleb (Taharka), i innych miejscowościach leżących wokół Meroe i Napaty. Zwyczaj budowy piramid jako królewskich grobowców przetrwał na tym obszarze zapewne aż do ok. 350 r. n.e., do momentu zniszczenia państwa w wyniku najazdów ludów koczowniczych.

${ }^{19}$ Sergio Donadoni (1990, s. 37) na podstawie zachowanych inskrypcji przypisuje tę budowlę zmarłemu pomiędzy 18 a 12 r. p.n.e. pretorowi, trybunowi ludowemu i septemwirowi epulonum Gajuszowi Cestiuszowi. Została zbudowana w ciągu 330 dni. Później została włączona w obręb murów Aureliańskich. Na jej ścianach i suficie zachowały się ślady malowideł w tzw. trzecim stylu pompejańskim. W Rzymie istniała jeszcze jedna
} 
egipskich budowli sięgnięto ponownie przy budowie grobowców w nowożytnej Europie, jak świadczą zachowane piramidy w wielu krajach (m.in. Niemczech ${ }^{20}$ i Polsce $\left.^{21}\right)$.

Z późniejszych okresów starożytności można wymienić jeszcze przynajmniej kilka przykładów budowli nawiązujących swym kształtem do piramid, wśród nich, zaliczany przez starożytnych do siedmiu cudów, niezachowany grobowiec Mausolosa, karyjskiego satrapy Halikarnasu, wzniesiony w latach 377-353 p.n.e. Spadzisty dach tej budowli przypominał grobowce faraonów ${ }^{22}$. Żydowski arystokrata Jazon w I w. p.n.e. postawił na cmentarzysku pod Jerozolimą ${ }^{23}$ grobowiec nawiązujący swym kształtem do piramidy.

Już od antyku powstawało wiele teorii tłumaczących powody wznoszenia tak oryginalnych budowli i celów, którym miały służyć. Niektóre z owych hipotez są wręcz zaskakujące. Większość z nich powstało przed odczytaniem egipskich hieroglifów, choć i w 2. poł. XIX w., gdy czytano już teksty egipskie, nadal tworzono hipotezy interesujące, wyraźnie odbiegające od oficjalnej nauki. Niewykluczone, że to właśnie te niemające podstaw teorie stały się źródłem określania czegoś nieprawdopodobnego jako ,,piramidalnej bzdury".

Przegląd poglądów na temat pochodzenia i przeznaczenia piramid należałoby zacząć od starożytności. Jeszcze Herodot widział w nich grobowce, ale Diodor Sycylijski już się wahał. $Z$ jednej strony widział w nich budowle wzniesione siłami pozaziemskimi (I 63, 7), a $\mathrm{z}$ drugiej zwykłe grobowce, w których pochowano faraonów (I, 64,4). Wydaje się, że do Diodora nawiązał w XIX w. Władysław Wężyk (1816-1848), który doszedł do ciekawego wniosku, że: „Świątynie i pałace Egipcyan nie są dla ludzi, a o ich piramidach można by powiedzieć, że nie są przez ludzi budowane!"24. Zapewne całkowicie nieświadomym naśladowcą Diodora Sycylijskiego i Władysława Wężyka jest dziś Erich von Däniken i jego liczni zwolennicy.

$\mathrm{W}$ antyku stawiano też pytania o przeznaczenie piramid, ponieważ wielu badaczom trudno było uwierzyć, iż te wielkie i wymagające pracy licznych robotników monumenty mogły służyć wyłącznie jako grobowce ${ }^{25}$. Utrata znajomości języka i pisma egipskiego związana z całkowitą chrystianizacją Egiptu ${ }^{26}$ spowodowała, że aż do czasu odczytania

piramida, tzw. watykańska, którą rozebrano w końcu XV w.; jej fundamenty odkryto w 1948 r. (Tietze 1999, s. 92-93).

${ }^{20}$ Tietze 1999.

${ }^{21}$ Zinkow 2009.

${ }^{22} \mathrm{Z}$ zachowanych źródeł wiemy, że Mausolos w 361 r. p.n.e. był w Egipcie w szeregach perskiej ekspedycji karnej; jego budowla, jak się oblicza, miała wysokość ponad $50 \mathrm{~m}$.

${ }^{23}$ Grobowiec Jazona, leżący w przy obecnej ulicy Alfasi w Jerozolimie, to rodzinny grobowiec saducejskiego rodu kapłańskiego powstały przypuszczalnie w II w. p.n.e. Łącznie w komorze grobowej znajduje się osiem pochówków typu kochim. Ostatni pochówek zaistniał w 30 r. n.e. (Levin 2007, s. 361). Ze starożytnych cmentarzysk jerozolimskich (Dolina Cedronu) pochodzi kolejny przykład - grobowiec Zachariasza zwieńczony piramidą (II w. p.n.e).

${ }^{24}$ W ężyk 1842, s. 37.

${ }^{25}$ Herodot pisze wyraźnie o tym, iż przez 20 lat przy budowie piramidy Cheopsa zatrudniano 100000 ludzi.

${ }^{26}$ O dziejach recepcji cywilizacji starożytnego Egiptu pisał Morenz 1969 i Zinkow 2006. 
pisma hieroglificznego przez Jeana-Françoisa Champolliona nie potrafiono wytłumaczyć wielu problemów z dziejów Egiptu. Jedną z tych zagadek stanowiły piramidy i ich przeznaczenie. Najczęściej widziano w nich tamę przeciwko piaskom pustyni, zbiorniki na wodę, spichlerze, latarnie dla wędrowców z pustyni, wieże obserwacyjne dla badania nieba $^{27}$, najrzadziej uznawano je za grobowce władców. Dla średniowiecznych Arabów były one też ,skarbcem”, w którym ukryto różne drogocenne przedmioty przed spodziewanym potopem, a ich budowniczym (architektem) był Hermes Trismesgistos ${ }^{28}$.

Jednym z ciekawszych wyjaśnień była próba powiązania ich z wydarzeniami biblijnymi. Myśl ta, żywa jeszcze w XIII w., o czym świadczą mozaiki stropu przedsionka kościoła św. Marka w Wenecji i baptysterium przy katedrze florenckiej, pojawiła się już u schyłku starożytności. Wówczas to Grzegorz z Nazjanzu (330-390 n.e.) uznał je za spichrze zbudowane na rozkaz biblijnego patriarchy Józefa, w których w ,latach tłustych” miały być gromadzone zboże na „lata chude”, które zapowiadał sen faraona. Za takim wykorzystaniem piramid opowiedział się jeszcze Niccolò do Poggibonsi oglądający je w połowie XV w., którego dzieło Libro d'altramare już w 1450 r. przetłumaczono na język niemiecki ${ }^{29}$.

Używana w językach europejskich nazwa tej monumentalnej budowli pochodzi z ję-

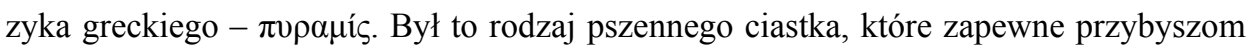
z Grecji przypominały te wielkie kamienne konstrukcje. Należy zwrócić uwagę, iż greckie słowo $\pi$ ù $\rho$ to także pszenica ${ }^{30}$. Stąd niedaleko do skojarzenia, iż budowle te należy łączyć w jakiś sposób z tym zbożem, co bardzo potem ułatwiło uznanie je za spichrze ${ }^{31}$. Warto też przypomnieć, iż pewną rolę w takim skojarzeniu mogła odegrać pamięć o roli Egiptu jako głównego spichlerza Cesarstwa Rzymskiego.

Do polskich „,spotkań” z piramidami początkowo - w średniowieczu - doszło w Rzymie, stolicy chrześcijaństwa, gdzie można było podziwiać piramidę Cestiusza

${ }^{27} \mathrm{~W}$ Polsce piramidy w roli obserwatoriów astronomicznych w starożytnym Egipcie widział Hieronim Borzęcki (1748-?), 1776, s. 39-41 piszący o nich „Jedne z nich przeznaczone były na mieszkanie osobne życie prowadzącym, drugie na pogrzeby królom którzy się wsławili. Wierz tych pyramid płasko się kończył i służył na miejsce do uważania obrotów planet". Płaski wierzch piramidy, o którym pisze Borzęcki, jest wynikiem usunięcia z piramidy jej zwieńczenia - piramidionu. Piramidy kamiennymi domami (Stein-Hause) nazwał też, podróżujący po Bliskim Wschodzie w roku 1737 Jonas Kortens (1743, s. 30). Należy widzieć tu zapewne wpływy czołowego austriackiego architekta epoki baroku, Johanna Bernharda Fischera von Erlacha (16561723) i jego dzieła o architekturze (Fischer von Erlach 1721).

${ }^{28}$ Graefe 1911; Hornung 1999, s. 160.

${ }^{29}$ Piramidy jako spichlerze patriarchy Józefa pojawiają się także we wcześniejszych wspomnieniach pielgrzymów, którzy dotarli do starożytnego Memfis. Anonim z Piacenzy [43] piszący ok. 570 r. wylicza dwanaście takich budowli w okolicy Memfis. Jednakże już w XIV w. swe wątpliwości co do takiego użytkowania piramid wysunął goszczący w Egipcie Wilhelm von Boldensele (ok. 1285 - 1338/1339). O Niccolò do Poggibonsi zob. Tietze 1999, s. 146.

${ }^{30}$ Inna teoria wywodzi nazwę budowli od innego słowa greckiego $\pi$ ù - ogień. Sądzi się, iż nazwa pochodzi prawdopodobnie od złoconego wierzchołka budowli, od którego odbijały się promienie słoneczne, tak że sprawiał wrażenie płonącego ognia. Nie znalazła ona jednak uznania w oczach ówczesnych uczonych.

${ }^{31}$ Teza ta była żywa w XIII w., o czym świadczą mozaiki stropu przedsionka kościoła św. Marka w Wenecji. 
i nieistniejącą dziś piramidę watykańską. Pod koniec XVI w. i w Polsce wzniesiono pierwsze grobowce - piramidy. Począwszy od baroku, ,piramidy” pojawiają się na terenie Europy jako elementy małej architektury ogrodowej w rezydencjach możnowładców i panujących. Specyfiką Polski tego czasu jest to, że egipskie elementy architektoniczne (obeliski, zwane piramidami) znalazły dodatkowo zastosowanie podczas ceremonii pogrzebowych. O dużym zainteresowaniu tego typu elementami niech świadczy chociażby to, że jeszcze w XVIII w. dla ozdoby katafalków podczas egzekwii przywożono „piramidy" $z$ Włoch ${ }^{32}$.

W literaturze staropolskiej mylono często pojęcia „piramida” i „obelisk”, co także $\mathrm{z}$ jednej strony komplikuje obecny odbiór polskiego spojrzenia na te budowle, a $\mathrm{z}$ drugiej strony mają one wyraźne konotacje z ceremoniami sepulkralnymi. Wyrazem tego są liczne diariusze z podróży chociażby do Stambułu. Maciej Stryjkowski (1547 - po 1582), który w 1574 r., w trakcie pobytu polskiego poselstwa (legacji) w Konstantynopolu zetknął się z wysłannikami z Egiptu, przebywającymi wówczas na dworze sułtana, podziwiał także przeniesiony tam w czasach Cesarstwa Rzymskiego oryginalny staroegipski obelisk $^{33}$, który nazwał piramidą:

Drugi zaś słup, albo kolumna, jest na kształt piramidis czworograni[a]stej, pochodzisty na trzech tylko łokciach mosiądzowych, z jednego kamienia marmurowego uciosany, wzwyż na 40 łokiet, który powiadają być arte magica postawiony, bo te i charaktery na nim dziwnie wyrażone świadczą, a na [301] fundamencie jego stara rada wyrzezana grecka, z wypisem greckim i łacińskim: Dificile quondam dominis parere servis ... Zową ten słup po włosku la gucia, igła ${ }^{34}$.

Wcześniej opis konstantynopolskiego obelisku pióra Erazma Otwinowskiego (1526-1614) znajdziemy na kartach Diariusza poselstwa Andrzeja Bzickiego (?-1567) z $1557 \mathrm{r}$ :

Tam niedaleko tego gmachu jest plac wielki który Athmeiden zowią. Na którym stoją trzy kolumny, kamienne dwie a trzecia spiżana. Tu jedna co najwyższa jest piramis, jako która z jednego kamienia uciosana figurami z ptaków i zwierząt po obu stronach, a jest bardzo wysoka, na stolcu z białego kamienia kwadratowego zbudowanym, na czterech słupach spiżanych na każdym rogu stolca postawiona, tak iż ją ze wszystkich czterech stron można podejrzeć. A na środku pod onym kamieniem kliniastym jest napis łaciński Teodozyusza cesarza którym wypisał ${ }^{35}$.

Przy opisie Konstantynopola (Dwór cesarza tureckiego i rezydencya jego w Konstantynopolu) pióra Szymona Starowolskiego (1588-1656) wydanym w Krakowie

\footnotetext{
${ }^{32} \mathrm{~W}$ archiwum rzymskim pod datą 14 czerwca 1776 r. odnotowano, że Ignazio Brocchi (1738-1802) wywoził z Italii do Warszawy „części nagrobków, piramidę z podstawą i urną, wszystko sycylijskim jaspisem i giallo z Sieny wykładane" (Tomkiewicz 1888, s. XXII). O wykorzystaniu tego typu przedmiotów w polskiej pompa funebris zob. Chrościcki 1974.

${ }^{33}$ O obelisku w Konstantynopolu zob. Abdel-Kader 1991, s. 117-131, gdzie dalsza literatura.

${ }^{34}$ Stryjkowski 1978 , s. 463.

${ }^{35}$ Otwinowski 1860, s. 21.
} 
w 1647, a wznowionym w 1858 r., znajdziemy kolejny przykład odnotowania faktu istnienia $\mathrm{w}$ tym mieście obelisku:

Pierwszy [rynek], który od dawnych wieków zowią Petromo, kędy stoi jedna piramis czworograniasta, z jednego kamienia wyrobiona, większa daleko, niżeli owa w Rzymie przed kościołem Piotra św. Dwie zaś piramidy są mniejsze, tak też wysokie, jako i owa pierwsza, ale cegłą odespodź podmurowane, a same są marmurowe ${ }^{36}$.

Wojciech Miaskowski (?-1654) w dzienniku z poselstwa do Turcji w 1640 r. również odnotowuje istnienie obelisku na placu Hat [Ilat] w Konstantynopolu ${ }^{37}$. Jeden z kilku znanych nam dzisiaj wersji diariuszy goszczącej w Konstantynopolu „legacyi” Rafała Leszczyńskiego (1650-1703) przynosi kolejny jej opis:

Wpół tego majdanu między pałacem a meczetem, z jednostajnego w kwadrat ciosanego kamienia, kilkadziesiąt łokci altitudinis in summitatae zaostrzona kolumna refert z każdej strony per modum napisów, dawne Egipcjanów simbolica indicia, na postumencie zaś leguntue greckie inskrypcyke i jedna łacińska a parte meczetu tymi wierszami continetur. Difficilis quondam Dominis parere serenis / Iussus et extinctis palmam portare tyranis / Omnia Theodosio cedunt sobolique prenni / Ter denis sic victus ego domitusque diebus ${ }^{38}$.

Wszystkie te informacje dotyczą obelisku Totmesa III (1479-1425 p.n.e.) wykonanego z jednego kawałka ausuańskiego czerwonego granitu, który zanim trafił do Stambułu, na teren hipodromu (Atmeidan), stał pierwotnie na południe od VII Pylonu świątyni w Karnaku w Egipcie.

Podobnie postąpił polski misjonarz Iwo (Józef) Drohojowski (1739 lub 1740-1811), co można stwierdzić, gdy opisuje ruiny budowli znajdujących się obok kolumny Pompejusza:

Tuż w pobliżu okazuią się mury zwalonego pałacu rozkoszney Kleopatry, w którym królewstwo, honor i życie utraciła. - Jey pamiątkę oznacza z bogatego porfiru wystawiona Piramida, trochę mnieyszey od kolumny Pompeiusza wysokości. Napisów dawnych na kolumnach i Piramidach wyrytych, teraźnieysi Egipcyanie ani przeczy tać, ani zrozumieć, dopieroż wytłomaczyć niepotrafią ${ }^{39}$.

Tę tradycję kontynuuje też Michał Sołtyk (1740-1815), który zresztą uważał piramidę w Gizie za grobowiec Cheopsa, gdyż pomieszczenie wewnątrz budowli nazywa grobem $^{40}$. Trochę gorzej sprawa przedstawiała się z jego wiedzą o piramidach (R. XXXI O Budownictwie), które pomylił z obeliskami: „W Egipcie zaś wystawiano piramidy, czyli obeliszki niezmierney wielkości; z tych niektóre dostały się do Rzymu i dotąd są

\footnotetext{
${ }^{36}$ Starowolski 1858 , s. 17.

${ }^{37}$ Miaskowski 1985, s. 69

${ }^{38}$ Leszczyński (1998, s. 162); autor pamiętnika lub wydawca opuścili jeszcze jeden wiersz napisu: Judice sub Proclo superas elatus ad auras (por. Abdel-Kadar 1991, s. 122); zbliżony opis znajduje się na

${ }^{39}$ Drohojowski 1812, t. I, s. 250, 251.

${ }^{40}$ Sołtyk 1784, cz. 1-2.
} s. 222. 
ozdobą tego Miasta, inne ieszcze stoią w Egipcie, z których naywiększy ma 500 stop wysokości"41. Być może owo mylenie obelisków z piramidami było wynikiem pojawiających się od XVI w. w książkach ilustracji drzeworytniczych, czy metalorytniczych, które przedstawiały piramidy egipskie jako budowle bardzo wąskie, a jednocześnie wysokie. Zapewne takie przedstawienie piramidy działało mocno na wyobraźnię i miało wpływ na uznanie jej za tożsamą z obeliskiem, zwłaszcza dla tych, którzy nigdy nie widzieli piramid in situ i nie mieli możliwości porównania wyobrażeń drzeworytniczych z oryginałami. Należy sądzić, że owe reprodukcje graficzne musiały bardzo mocno się zakorzenić w pamięci mieszkańców Polski.

Wydaje się, że w innych krajach europejskich równie długo nie potrafiono zdecydować się na rozdzielenie pojęć ,piramida” i ,obelisk”, jeżeli w opublikowanym w 1743 r. w języku polskim Dziejopisie starożytnym francuskiego uczonego Karola Rollina znajdujemy także opis tej budowli zbliżony do wyżej przedstawionych polskich definicji piramidy: „Piramida iest to kamień, albo pełny albo dęty, swoie łoże z czworga gran maiący, a w górze zaostrzony"42. Benedykt Chmielowski (1700-1762) wymienia szereg faraonów, takich jak Menes, twórca dynastii z Memfis i ,fundator kilku piramid”. Nie potrafi się jednak zdecydować, w jakim celu budowano piramidy, przedstawiając różne teorie, wzajemnie sprzeczne ${ }^{43}$. Ostatecznie wydaje salomonowy wyrok: „Jest wielu zdanie, że niektóre Pyramidy Żydzi murowali, będąc w Egypskiey niewoli na Szpichlerze, albo na Groby królow"44. Podaje oczywiście opis wyglądu piramid, ich lokalizację a także liczne ciekawostki o ich budowie przejęte z Herodota i Diodora. Sfinksa niestety pomylił z piramidą Rodopis: „Iedna Rhodopy nierządney, piękna, wysoka na łokci 60 albo 70 summą z nierządu zebraną od niey wystawiona. Teste Plinius ${ }^{45}$. Na niey głowa Kamienna z szyią teyże Rhodopy. Na te introitus czyli piaskiem zasypany, czyli umyślnie ukryty"46. Przeprowadza również interesującą etymologię nazwy piramidy. Jego zdaniem nazwa związana jest $\mathrm{z}$ funkcją tych budowli jako spichrzy wystawionych przez Józefa i pochodzi od słowa pyros - pszenica. Pojawiają się też bardziej radykalne opinie. August Moszyński (1731-1786) piramid nie widział, ale tak o nich nieżyczliwie wyrażał się: „Co do piramid, to widzę $\mathrm{w}$ nich kamieniołomy przeniesione $\mathrm{z}$ jednego miejsca na drugie. Zbyteczny jest geniusz do podjęcia takiego dzieła; próżność i pieniądze wystarczą, aby tyle dokonać" ${ }^{47}$.

Mniej więcej w tym samym czasie w Niemczech profesor Friedrichs-Universität Bützow, Samuel Simon Witte (1738-1802) orzekł, że piramidy nie zostały zbudowane rękoma ludzkimi, ale stanowią efekt działalności wulkanicznej. Napisy na obeliskach

\footnotetext{
${ }^{41}$ Soltyk 1784, s. 89.

${ }^{42}$ Rollin 1743, s. 63.

${ }^{43} \mathrm{Chmielowski} 1754$, t. I, s. 666, 667 i w t. II, s. 655-656.

${ }^{44}$ Chmielowski 1754, t. II, s. 655.

${ }^{45}$ Plinius Maior, Hist. Nat. XXXVI, 75.

${ }^{46} \mathrm{Chmielowski} 1754$, t. I, s. 667.

${ }^{47}$ Moszyński 1970, s. 231.
} 
uznał za efekt działania specjalnego rodzaju ślimaków toczących kamień ${ }^{48}$. Teoria głosząca, że budowa piramidy to efekt wtórny innych inwestycji starożytnych Egipcjan „magazyn” wydobytego i zbędnego kamienia, co jakiś czas pojawia się i obecnie ${ }^{49}$. Nie najlepszą opinię o piramidach miał również Euzebiusz Słowacki (1773-1814), zarzucający piramidom egipskim brak gracji ${ }^{50}$.

Prastary pogląd, iż piramid nie budowano jako groby władców, widoczny jest w literaturze polskiej jeszcze w 2. poł. XIX w., gdy Antoni Złotnicki (1857-1924), nie potrafiąc odpowiedzieć na nurtujące go pytanie: w jakim celu je wznoszono, w swych wspomnieniach z podróży do Egiptu napisał:

\begin{abstract}
Naród egipski nie dałby się zaprządz do tak olbrzymiej i uciążliwej roboty, gdyby chodziło jedynie o zachowanie mumii królewskiej. Jeżeli zważymy, że cywilizacja egipska była w treści swej religijną, to musimy przyznać, że piramidy nie mogły być pozbawione charakteru religijnego, wtedy nawet, gdy cel ich właściwy inne miał przeznaczenie. Nic też dziwnego, że królowie, którzy je wznosić kazali, pragnęli mieć w nich swe grobowce. A zresztą stawianie piramid tak wiele zajmowało rąk ludzkich, że mogło ich braknąć do budowy rzeczywistych grobowców, jaki każdy król za życia jeszcze sobie fundował. W każdym razie, gdy król umierał pierwej, nim zdołano ukończyć budowę jego grobowca, grobowiec ten pozostawał niedokończonym; następny król bowiem, zajęty swym losem pośmiertnym, nie miał czasu myśleć o szczątkach swego poprzednika. Budowa piramid tymczasem zawsze prowadzoną była do końca; śmierć króla nie przerywała jej nigdy ${ }^{51}$. Ztąd wynika, że piramidy nie były właściwie grobowcami, lecz ważniejsze, bo obchodzące cały kraj, miały przeznaczenie. Gdy weźmiemy pod uwagę rozkład topograficzny piramid, oraz tę okoliczność, iż nie kątami, lecz fasadami zwrócone są przeciw wiatrom zachodnim, musimy dojść do wniosku, że stawiano je w celu powstrzymania piasków pustyni, grożących zasypaniem doliny Nilu. Znając kierunek [h]uraganów piaskowych, usiłowano powstrzymać bieg ich w tych miejscach, gdzie łańcuch gór Libijskich nie wystarczał. Budowano je grupami w obwodzie 20 do 25 kilometrów. Od Farsum (w odległości około 70 kilometrów od Kairu) aż do Nubii nie ma piramid, gdyż łańcuch gór Libijskich nie przerywa się nigdzie na tej rozciągłości. Dopiero w górnej Nubii ukazują się piramidy mniejsze, ale liczniejsze natomiast niż w Egipcie. Ażeby nie niszczyć łańcuch gór Libijskich, będących wałem ochronnym Egiptu, materiał do budowy piramid sprowadzanym być musiał z gór Arabskich. Największy wyłom istnieje pomiędzy piramidami Kedżyala i Kebir, to też żadnej nie ma tam roślinności, gdy tymczasem taż sama dolina obfitą posiada roślinność w miejscu, gdzie zabezpieczoną jest od piasków pustyni przez piramidy Dżyzeh ${ }^{52}$. Podziw, jakiego doznajemy na widok tych olbrzymich pomników, pozostaje więc niezakłóconym przez myśl o ich bezużyteczności. Przeciwnie, zwiększa się on jeszcze, gdy uświadomimy sobie cel, w jaki stawiane były te olbrzymy. Są one świadectwem potęgi ducha ludzkiego, wcześniejszymi od wszelkich tradycji historycznych, oraz najstarszemi i najpewniejszemi dowodami dawnej cywilizacji człowieka ${ }^{53}$.
\end{abstract}

Średniowieczna tradycja arabska, na którą powoływał się już w XVII w. Johan Georg Herwart von Hohenburg ${ }^{54}$ także uznawała piramidy za wał ochronny przed wylewami Nilu.

${ }^{48}$ Witte 1789 , s. $182,183$.

${ }^{49}$ Bochnacki 1994.

${ }^{50}$ Słowacki 1824, s. 97.

${ }^{51} \mathrm{~W}$ rzeczywistości po śmierci faraona jego następca pospiesznie wykańczał grobowiec, na tyle tylko, by można było umieścić w nim sarkofag ze zmarłym.

${ }^{52}$ Współczesna miejscowość to Giza, obecnie część Kairu.

${ }^{53}$ Złotnicki 1891, s. 552.

${ }^{54}$ Hohenburg 1623. 
Do innych wniosków o powodach budowy piramid doszedł Hugo Kołąajaj (17501812). W Rozprawie IV § III napisat:

[...] najdawniejsze piramidy znajdują się w wyższym Egipcie, co dowodzi, że między owymi potomkami uratowanych w potopie ludzi było tak wielkie uszanowanie dla gór, na których pewnie obchodzili pamiętkę tego okropnego zdarzenia, jakie jest u chrześcijan dla góry Kalwarii, której imię rozniesione zostało po wielu odległych od Palestyny krajach ${ }^{55}$.

W innym miejscu uznał, że piramidy wyznaczały granice między Azją a Afryką ${ }^{56}$. Z kolei niemiecki nauczyciel Johann Matthias Schroeck (1. poł. XIX w.) w swym podręczniku dla młodzieży szkolnej nie potrafił zdecydować się na jedną interpretację piramid, łącząc znane wówczas teorie o przeznaczeniu tych budowli w jedną całość i wskazując na ewolucyjne zmiany w ich wykorzystaniu: „Gmachy te s początku były poświęcone na cześć słońca, potem obrócone na groby królów, nareszcie na pamiątkę ich fundatorów" ${ }^{\prime 57}$. Ciągle powraca teoria zgodna z tradycją chronologii antycznej, że starszą formą ,piramidy” był obelisk, wzniesiony zgodnie z Herodotem w Heliopolis, w świątyni słońca przez Sesostrisa, a dopiero później jako budowla przeznaczona na grobowiec przez Cheopsa.

Jeszcze więcej problemów z piramidami miał księgarz i antykwariusz krakowski Ambroży Grabowski (1782-1868) ${ }^{58}$. Znał on aż trzy panujące w ówczesnej nauce teorie na ich temat: piramidy to grobowce, spichlerze lub obserwatoria astronomiczne. Niestety, żadna z nich nie znalazła uznania w jego oczach. Osobiście sądził, że piramidy nie mogły być grobowcami, ponieważ pod Tebami, najbardziej głośnej stolicy państwa faraonów, nie ma podobnych budowli; nie mogły być też spichrzami, bo ich konstrukcja i układ wewnętrzny nie odpowiadał wyobrażeniom o magazynach zbożowych. Nie mogły też być obserwatoriami astronomicznymi, bo zbyt wiele było ich zgromadzonych na niewielkiej przestrzeni. Postawione przez siebie pytanie, po zaprezentowaniu znanych sobie poglądów, Grabowski więc pozostawił bez odpowiedzi, nie potrafiąc czy też nie chcąc zdecydowanie opowiedzieć się za którąs z zaprezentowanych przez siebie teorii.

Poznański nauczyciel historii Elogiusz Zakrzewski (?-1884), w swym podręczniku szkolnym powtórzył owe bałamutne informacje pisarzy antycznych o obeliskach i piramidach. Próbował też połączyć różne teorie o przeznaczeniu piramid: „Lubo piramidy miały zapewne wyższe znaczenie i były pamiątkami, tak wypadków nadzwyczajnych, jak pojęć symbolicznych, służyły one zarazem za grobowce Króli",59.

\footnotetext{
${ }^{55}$ Kołłątaj 1972, s. 463 (Rozprawa IV § III); zwracam uwagę, że wśród XX-wiecznych teorii o pochodzeniu Sumerów także wskazówką ich „góralskiego” rodowodu są zikkuraty (Bielicki 1966 s. 51-52; Braun 1971 s. 48).

${ }^{56}$ Kołłątaj 1972, s. 496-497. Pogląd, że Egipt należy jeszcze do Azji funkcjonował już w starożytności. Spotykamy się z nim także później.

${ }^{57}$ Schroeck 1813, s. 54.

${ }^{58}$ Grabowski 1822, s. 99, 100.

${ }^{59}$ Zakrzewski 1850, s. 25.
} 
Ksiądz Józef Sebastian Pelczar (1842-1924) - późniejszy biskup przemyski i święty, w czasie swej podróży po Egipcie odwiedził piramidy w Gizie, podobnie jak wielu turystów wspiął się na szczyt piramidy, nie ominął również jej wnętrza, a potem tak je opisał: „Nazwa piramid pochodzi ze słów staroegipskich p-uro-ma, co znaczy grób królewski - albo też: par-ammah, tj. dom świata podziemnego"60.

Dostarcza nam także informacji o pochodzeniu piramid:

Co do początku piramid różne są zdania. Niektórzy uczeni odnoszą je do r. 2300 przed Chr. i przypisują Faraonom Cheopsowi (Chufu) i bratu jego Chefrenowi (Chafra). Inni uważają piramidy za dzieło obcych pokoleń, które do Egiptu wtargnęły; a co do ich celu, sądzą, że służyły nietylko za grobowce, ale za miejsca schadzek i nauk tajemnych czyli misteryj egipskich, a nawet za wały graniczne, mające powstrzymać szerzącą się coraz dalej pustynię; Hebrajskie tradycye nazywają chełpliwie synów Izraela twórcami piramid i przeznaczają takowe na śpichrze Józefa! ${ }^{61}$

Ksiądz Jakub Górka (1864-1917) wygodnie, bo tramwajem elektrycznym, dojechał do piramid. Zastanawiał się nad celem ich wzniesienia. Rozważał prawdziwość hipotez mówiących, że piramidy stanowiły zapory przeciwko piaskom pustyni, wieże obserwatoriów astronomicznych, drogowskazy dla wędrowców po pustyni, czy nawet olbrzymie zbiorniki na wodę. Wszystkie jednakże odrzucił, uznając je ostatecznie za grobowce władców. Jednakże nie zapomniał również o symbolice kształtów idealnych: „Czworokąt czy kwadrat w połączeniu z trójkątem wyraża tę myśl, że bóstwo ogarnia wszechświat. Jak piramida strzela śmiało ku niebu, tak wszystko dąży ku Bogu. Jak nasze wieże kościelne mówią żywo do ludu: »w górę serca!«, tak przemawiały i piramidy"62.

Najdalej w swoich poglądach na temat przeznaczenia piramid posunął się w latach 30. XX w. lwowski architekt, profesor Politechniki Lwowskiej, Jan Sas-Zubrzycki (1860-1935). W swym niewielkim artykule Znaczenie piramid egipskich w lwowskim „Czasopiśmie Technicznym” z 1928 r., wydanym w tym samym roku również w formie osobnej nadbitki liczącej 16 stron. Swój najważniejszy wniosek sformułował już na pierwszych stronach broszury. Według niego: „Piramidy są obrazem kształtowania dla zdumienia człowieka wyrazem myśli boskich przy pomocy prostoty najpierwotniejszej" ${ }^{\prime 63}$. Piramida była więc budowana sama dla siebie, czyli jak napisał:

[...] nie była stawianą dla grobu królewskiego, nie była poświęconą myśli na podobieństwo świątyni ${ }^{64}$, piramida nie mogła służyć dla spostrzeżeń obrotu gwiazd na niebie i nie wyobrażała bogactwem skarbów

${ }^{60}$ Pelczar 1875 , t. II, s. 39, przyp. 1.

${ }^{61}$ Pelczar 1875 , t. II, s. 40.

${ }^{62}$ Górka 1913, s.181.

${ }^{63}$ Sas-Zubrzycki 1928, s. 5.

${ }^{64}$ To zapewne nawiązanie do poglądów bawiącego w 1721 r. w Egipcie przyrodnika Thomasa Shawa, zdaniem którego wnętrze piramidy Cheopsa nie nadawało się na grób, a stanowiło świątynię. Znajdujący się w komorze sarkofag należy łączyć z mistycznym kultem Ozyrysa. Komora miała podziemne połączenia z innymi piramidami i Sfinksem. Podobnego zdania byli też lekarz Charles Perry (1743), Cornelius de Pauw (1774, s. 257).Wydaje się, że wyobrażenie piramidy jako świątyni w opinii publicznej ugruntował wydaną w 1771 r. po raz pierwszy powieścią Sethos. Jean Terrasson (1670-1750). 
przewagi samowładztwa ponad narodami - nie! to wszystko mogłoby ubocznie wynikać z istoty powstania utworu, ale nie stanowiło celowości. Komory królewskie z chodnikami są taką drobiazgowością w porównaniu do ogromu bryły całej, że nazwać je możemy tylko wyzyskaniem zadania koniecznego dla korzyści przypadkowej. Tem zadaniem koniecznem to myśl ujawnienia obrazowo w przestrzeni składu całości z kilku części pojedyńczych, aby zapomocą kształtu najpierwotniej złożonego, w sposób prostoty najbardziej pomnikowej, uwiecznił się duch porządku i zgodności, czyli pokoju i jedności. Z przyczyny takiej bylibyśmy najbardziej skłonni do powtórzenia zdania, że piramida egipska to wyobrażenie nieśmiertelnej duszy! ${ }^{65}$

W celu udowodnienia swoich tez dokonuje licznych działań matematycznych, oblicza wielkości, stosunki różnych pomiarów, by w efekcie dojść do wniosku:

Wszystkie zatem trzy piramidy opierają się o kształtowanie jedno i to samo, przy zachowaniu stosunku z szeregu złotego, aby na podstawie o 8 częściach wznieść w górę wysokość o 5 częściach takich samych. Trójkąt egipski, jako trójkąt najpiękniejszy, ma przeto boki do podstawy nachylone pod kątami o wiele większymi jak $45^{\circ}$. To właśnie jest znamieniem zasadniczem trójkąta piękności i w Egipcie panującego i w sztuce ostrołucznej, zwłaszcza w stylu naszym polskim, stylu nadwiślańskim, rozpowszechnionego. Ostrołęka polska posługuje się promieniem, który równa się 5/8 rozpiętości ${ }^{66}$. Mniej więcej kąty spodkowe wynoszą przy trójkącie egipskim po $52^{\circ}$ zatem kąt wierzchołkowy ma $76^{\circ}$ zamiast $90^{\circ} 67$.

Jego zdaniem stał się on podstawą do wykreślania wszelkich figur geometrycznych w średniowieczu, gdyż: „Ten sam trójkąt mający za wysokość czyli przyprostokątnię trzy jedności symbolizował troistość Bóstwa" ${ }^{\text {"68 }}$. W ten sposób „trójkąt egipski” wprowadzony został jako ważny element do rozważań nad nadwiślańską architekturą, co jak się wydaje - było obsesją w całej twórczości Jana Sas-Zubrzyckiego, usiłującego w swych licznych publikacjach udowodnić rodzimość rozwiązań architektonicznych w kraju, ich polskie korzenie i rozprzestrzenianie się znad Wisły po całej Europie i świecie.

Koniec XIX w. to moment pojawienia się nowych teorii, które przynależą już do pseudonauki, zwanej powszechnie piramidologią. Wymienić należy tu artykuł Stefana Pawlickiego (1839-1916) noszący tytuł Tajemnice wielkiej piramidy ${ }^{69}$, zawierający informacje nie tylko ściśle naukowe o badaniach nad piramidami, ale przede wszystkim najnowsze w tym czasie teorie Piazzi Smytha (1819-1900) i ks. Moigno.

W Polsce poglądy na piramidy zaczęły się zmieniać częściowo już w XVII w. Wpływ na to miały ukazujące się wówczas rozprawy naukowe i relacje naocznych świadków. Duży rozgłos zyskała w Polsce pielgrzymka do Ziemi Świętej i Egiptu Mikołaja Krzysztofa Radziwiłła zwanego „Sierotką” (1549-1616). Od momentu wydania drukiem jego wspomnienia z podróży cieszyły się dużą popularnością i doczekały się na przestrzeni XVII i XVIII w. licznych wydañ ${ }^{70}$. Co ciekawe, krążyły po Polsce także

\footnotetext{
${ }^{65}$ Sas-Zubrzycki 1928, s. 5.

${ }^{66}$ Sas-Zubrzycki 1928, s. 13.

${ }^{67}$ Sas-Zubrzycki 1910, s. 67.

${ }^{68}$ S a s-Zubrzycki 1910, s. 67 (czyżby była to próba nawiązania do chrześcijańskiej Trójcy św.?).

${ }^{69}$ Pawlicki 1877.

${ }^{70}$ Jego wspomnienia z pielgrzymki miały kilka wydań w wersji łacińskiej w Bunsbergae (Braniewo) 1601, w Antwerpii w 1614, w Jaurinum (Raba na Węgrzech) w 1753; w Krakowie w 1765.
} 
w odpisach rękopiśmiennych ${ }^{71}$. W tym samym czasie dokonano ich licznych tłumaczeń $\mathrm{z}$ języka łacińskiego na polski ${ }^{72}$ i inne języki narodowe Europy ${ }^{73}$.

W połowie XVII w. osiadł Włoch Tytus Liwiusz Boratini [Buratini] (1617-1681), który wcześniej, w latach 1637-1641, będąc w Egipcie, prowadził wraz z Janem Greavesem (1602-1652) badania nad piramidami, dokonując ich pomiarów ${ }^{74}$. Oryginalne prace samego Boratiniego poświęcone tej problematyce niestety nie zachowały. Rękopis jego podstawowego dzieła o Egipcie - Niloscopio ukradziono mu wraz z innymi przedmiotami podczas napadu rozbójników w kwietniu 1645 r. na Węgrzech, w drodze z Polski do Wenecji. Później, w 1664 r., powrócił do tematyki egipskiej pisząc rozprawę Nouva dimostratione dell'inondatione del Nilo. Reminiscencje z badań prowadzonych przy piramidach przewijają się także w zachowanym jego dziele Misura universale wydanym w Wilnie w $1675 \mathrm{r}^{75} \mathrm{~W}$ dziele wielkiego polskiego polihistora Jana Jonstona (1603-1675) z Leszna, O stałości natury, wydanego po łacinie w Amsterdamie w 1634 i po angielsku w Londynie w 1657 r., możemy dowiedzieć się, że:

Sandeus $^{76}$, opisując swe podróże mówi także i o piramidach. Wedle jego opowieści wejścia do ich wnętrza były bardzo ciasne, tak że musiał iść zgięty. Ponadto dodaje, że w większej sali, wyłożonej marmurem tebańskim, widział grobowiec o długości siedmiu i szerokości czterech stóp. Podobno spoczywało w nim ciało budowniczego piramidy Chereopsa ${ }^{77}$.

Piramidy i obeliski stawiano jedynie dla ozdoby i na pokaz, a nie ze względu użyteczności ${ }^{78}$.

Od XVIII w. wzrasta znaczenie popularyzatorskie wydawnictw encyklopedycznych, różnego rodzaju słowników. W jednym z nich, Zbiorze Potrzebnych Wiadomości, biskup Ignacy Krasicki (1735-1801) o piramidach napisał:

Piramidy egipskie, między cuda świata policzone, że od dawnych tamteyszych królów stawiane były, rzecz pewna, ale w szczególności, iak się zwali każdey fundatorowie, żadney o tym pewności nie masz.

\footnotetext{
${ }^{71}$ Alexandrowicz 1976.

${ }^{72}$ W polskim tłumaczeniu Wargockiego w: Krakowie w 1607, 1609, 1611, 1617, 1628, 1683, 1745, 1756, we Wrocławiu w 1847. W XX w., po dotarciu do oryginalnych rękopisów wspomnień radziwiłłowskich, wydał ponownie je w 1925 r. Jan Czubek, zaś w roku 1962, używając innych kryteriów edytorskich, Leszek Kukulski.

${ }^{73}$ Niemieckie w 1603 i w 1609 (wydane we Frankfurcie w zbiorze: Reisebuch in das Heilige Land); rosyjskie: w 1787 i 1879 (to ostatnie przygotowane do druku przez P. A. Hilterbrandta). W 1990 r. po raz pierwszy wersję treterowską wydała w języku litewskim Ona Matusevičiūtė, zaś w 1994 r. ukazała się białoruska wersja językowa pamiętników w przekładzie Siargieja Šupa, bogato ilustrowana rycinami z XVII- i XVIII-wiecznych dzieł. Widać renesans zainteresowania pamiętnikami i samym pamiętnikarzem, na którego temat powstało również wiele opracowań biograficznych.

${ }^{74}$ Opublikował je w Londynie w 1646 r. (Greaves 1646).

${ }^{75}$ Ponownie wydał ją Ludwik Birkenmajer w 1897 r. w Krakowie.

${ }^{76}$ Jan Jonston odsyła prawdopodobnie do dziennika podróży zmarłego w 1642 r. angielskiego podróżnika, który w 1610 r. odwiedził Egipt - George’a Sandysa 1615.

${ }^{77}$ Jonston 1960, s. 65. Błędna wersja imienia Cheops, władcy IV Dynastii.

${ }^{78}$ Jonston 1960 , s. 106.
} 
Massy te niezmierne dziwiące dotąd pielgrzymów, okrywały groby fundatorów swoich. W Rzymie dotąd iest nadgrobek Celssyusza w piramidę z kamienia ciosowego tak ułożony, iż iedna połowa za murami mieyskimi, druga w murach zostaie ${ }^{79}$.

Dużą rolę w kształtowaniu poglądów o miejscu piramid w życiu Egipcjan odgrywały, w miarę rozszerzania się zasięgu szkolnictwa, podręczniki szkolne. Pijar Dominik Aleksander Gabriel Szybiński (1730-1799) w swym podręczniku do nauki historii tak przedstawił wierzenia Egipcjan w życie pośmiertne i miejsce piramid w nich:

Próżna chluba była pobudką królom Egipskim do wystawowania Piramid: sadził się jeden nad drugiego, kto wspanialszą i większą zostawi swemu ojcu albo sobie samemu w ogromnej piramidzie pamiątkę; co im przy despotycznych rządach (robiąc wszystko swemi poddanemi, albo niewolnikami) łatwo wykonać było. Najbardziej zabobonność do tego przyczyniała się. Piramidy bowiem były królów grobami. Popi egipscy zwani Chechdamatim $^{80}$ albo choen ${ }^{81}$ nauczali, iż dusza w tysiąc lat powróci do swego ciała. Chciano więc przez ten wszystek czas konserwować ciało, aby dusza powracająca nienaruszone zastała. Na ten koniec zaprawowano trupy balsamami z dziwnym bardzo przemysłem, i do tego jeszcze, zapobiegając wszelkim zepsucia powierzchniowym przypadkom, w ogromnych skałach misternie wewnątrz wykowanych zamykano. Królowie i przedniejsi z Egipcjan na przepych takowe groby budowali, dawali im kształt piramidów, jako najtrwalszy przeciwko słotom i rozmaitym powietrza odmianom. Tak więc trupy przejęte balsamami, ukryte w niedostępnych miejscach, w ogromnych złożone głazach, nad pojęcie ludzkie od czterech tysięcy lat i więcej konserwowały się, które momiami pospolicie zowią. Piszą Arabowie, iż jeszcze przed przybyciem Abrahama do Egiptu na kilka set lat niejaki król egipski Sauryd ${ }^{82}$ pierwszy był wynalazcą grobu w kształcie piramidy, za którego przykładem następcy idąc, z niesłychanym kosztem takowe wystawiali gmachy; przydają oni, iż pewny z królów egipskich zaprzątniony takim dziełem, cztery miliony każdego dnia na sam czosnek, cebulę, pory dla robotnika, nie rachując innego żywienia i wydatków, expensował $[\ldots]^{83}$.

Jak sądzę, Szybiński podstawowe informacje o piramidach zaczerpnął z Historii Naturalnej Pliniusza Starszego (XXXVI, 75), rozbudowując je o własne przemyślenia i zdobytą wiedzę od innych autorów.

Biskup Władysław Łubieński (1703-1767) również opowiedział się za sepulkralnym przeznaczeniem piramid, dodając podobnie jak Szybiński, jako ciekawostkę, że: „Oprócz zaś innych wielu inskrypcyi rzemieślnicy wyrazili literami expansę na samą

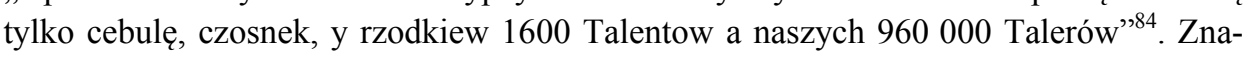

\footnotetext{
${ }^{79}$ Krasicki 1781 , t. II, s. 366.

${ }^{80}$ Nie udało mi się znaleźć egipskiego odpowiednika tego tytułu kapłańskiego.

${ }^{81}$ Prawdopodobnie przytoczona tu nazwa wywodzi się z koptyjskiego xont mającego rodowód w staroegipskim Hm-nTr 7,\& (Wörterbuch 1971, t. III, 88 oraz Černý 1976, s. 288); Jablonski (1752, s. XCI) zapisał tę nazwę jako p-xont.

${ }^{82}$ Al-Maķrīzī (1364-1442) [Gra efe 1911, s. 49], powołując się na Ibrāhima ben Waşif Šāh al-Kātib, podaje genealogię Saurida - miał być synem Sahlūk, syna Širbāka, syna Tūmiduna, syna Tadrasuna, syna Husala, pierwszego króla Egiptu przed potopem. Piramidy wzniósł dla ochrony przed zbliżającym się potopem talizmanów, skarbów i całej wiedzy tajemnej starożytnych Egipcjan.

${ }^{83}$ Szybiński 1772, t. I, s. 33, przyp. b.

${ }^{84}$ Władysław Łubieński 1740, s. 627.
} 
czące miejsce w rozpowszechnianiu wiedzy o piramidach miały ukazujące się wspomnienia podróżników, którzy je zobaczyli. W XVIII w. po Egipcie podróżował Jan Potocki (1761-1815), który tak opisał swe wrażenia z pobytu w Gizie:

Druga piramida otoczona jest obszernym podziemiem, gdzie znajdują się jaskinie, ozdobione hieroglifami; w jednej z tych jaskiń zachowała się bardzo piękna płaskorzeźba, przedstawiająca wszystkich bogów Egiptu. Z przykrością ujrzeliśmy, że została uszkodzona przez czcigodnego marabuta, który, wybrawszy to miejsce na swoją pustelnię, rozpoczął pobożne ćwiczenia od pastwienia się nad zabytkiem ${ }^{85}$.

Wydaje się też, że pewien wpływ, chociaż jak sądzę jednak mocno ograniczony, z uwagi na niewielką liczbę osób, które studiowały wówczas, na obraz roli piramid w wierzeniach Egipcjan mogły mieć też uniwersytety. Dziwiętnastowieczny profesor Uniwersytetu Jagiellońskiego Antoni Małecki ${ }^{86}$, w swych poglądach nie bardzo odbiega od poprzedników z XVIII w., gdy w rozdziale X (Archeologia, s. 171-184) stwierdza, że:

Piramidy i groby egipskie, obeliski, świątynie, pałace - pokryte bezlikiem symbolów, płaskorzeźb i hieroglificznych rysunków - wszakże to już wszystko, co się po tym wielkim niegdyś narodzie pozostało. Jestto jakby ogromna księga, w której mało kto czytać potrafi, zapisana przed wiekami, a pełna tajemnic o pokoleniu, które niewiadomo jeszcze, ile wpływu wywarło na późniejsze narody ${ }^{87}$.

Zainteresowanie piramidami znalazło też swoje odbicie w prasie. Wydawana w Poznaniu „Oświata. Tygodnik katolicko-narodowy dla stanu średniego” zamieściła wiele artykułów poświęconych problematyce egipskiej. W roczniku III z 1878 r. w cyklu artykułów poświęconym „cudom” świata, aż dwa odcinki Fr.[anciszek] Xaw.[ery] T.[uczyński] (Wujaszek) poświęcił piramidom ${ }^{88}$. Opisując owe starożytne cuda świata, przytoczył on dosyć rzetelne informacje o piramidach, sposobie ich budowania i zastosowaniu jako grobowców królewskich.

Redaktorzy warszawskiego „Opiekuna Domowego” zdecydowali się na publikację artykułu Kazimierza Mejera o piramidach, z trzema rycinami przedstawiającymi piramidy z Gizy ${ }^{89}$. Z tego artykułu niewiele wprawdzie dowiemy się o samych budowlach, a więcej o sztuce i wierzeniach egipskich, ale za to znajdziemy w nim bardzo cenną informację o dwóch małych rzeźbach sfinksa, stojących przed jakimś domem na Lesznie w Warszawie.

W artykule Karola Maciejowskiego Siedem cudów świata, w warszawskim „Przyjacielu Dzieci” nie mogło zabraknąć informacji o piramidach ${ }^{90}$. Zdaje się, że rocznik jedenasty w ogóle nastawił się na ich prezentację, gdyż znajdziemy tu także poemat Juliusza

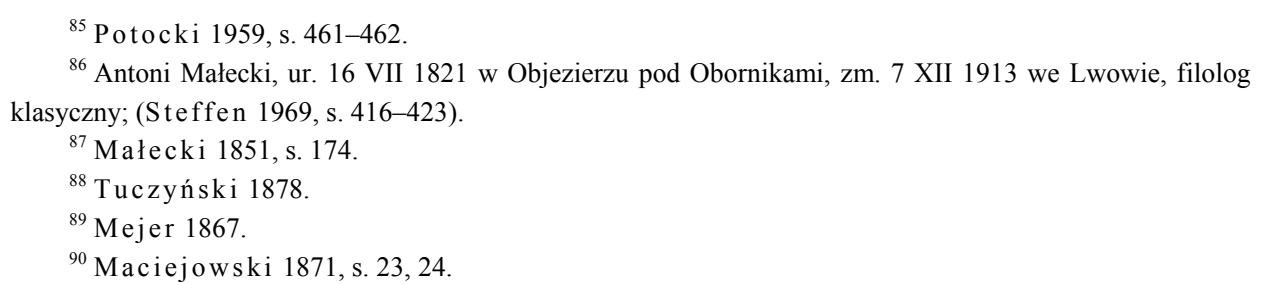


Słowackiego Nawiedziny piramid ${ }^{91}$ czy Widok piramid $w$ Egipcie (wzięty $z$ miejsca gdzie dawniej stało miasto Memfis) ${ }^{92}$.

W badaniach nad piramidami zastanawiano się wielokrotnie nad czasem ich powstania. Jednym z polskich uczonych, który poważniej potraktował ten temat był Hugo Kołłątaj ${ }^{93}$. W swoich Notach do rozprawy $I V$ wyodrębnia dwa skupiska piramid: jedno pod Memfis, a drugie pod Tebami (być może chodziło mu o tebańską Dolinę Królów, gdzie nie stawiano piramid lub jednak o piramidy z Meroe). Odrzuca przytoczone przez Barthélemy d'Herbelotha de Molainville ${ }^{94}$ (Biblioth. orient. p. 311) opinie arabskie, jakoby piramidy miał zbudować Gian-ben-Gian panujący przed Adamem. Co do ustalenia chronologii miał dylemat, gdyż znane mu źródła antyczne podawały sprzeczne daty. Zdaje się, że znalazł salomonowe wyjście z tej sytuacji, uznając piramidy tebańskie za najstarsze, datując je za Diodorem Sycylijskim na 3400 lat p.n.e. Powołując się zaś na Gogueta $^{95}$ („Mem. de l'Acad des Inscr.” r. 1761, s. 10), który odwoływał się do Homera, uznał, że piramidy memfickie są młodsze i datował je na rok 1000 p.n.e.: „Zdaje się wszelako, iż te obydwie daty utrzymać się mogą, naznaczając 1000 lat piramidom przy Memfis, a 3400 piramidom przy Tebach" ${ }^{\text {" }}$.

Jeszcze więcej problemów miał wspomniany juz Ambroży Grabowski z datowaniem piramid. Pisze zatem:

Nie wiadomo bynaymniey ani czasu kiedy, ani przez kogo stawiane były. Ten tylko wniosek zdaie się bydź prawdy bliskim iż gust wprowadzenia podobnych budowli tylko w pewnym okresie czasu u królów Egipskich panował, i królom pokolenia Faraonów był właściwym, którzy nie dłużey nad 200 lat Egiptem rządzili ${ }^{97}$.

Powstanie piramidy Cheopsa umieszcza jednak na 3000 lat od czasów mu współczesnych. Uważał wprawdzie, że brakowało na to dowodów, iż „Niegdyś piramidy okryte były hieroglifami, lecz to zapewne ostry ząb czasu zatarł, bo nowsi podróżopisarze ani śladu nie znayduią"98.

W rezultacie prowadzonych badań nad dziejami polskiej recepcji wiedzy o starożytnym Egipcie wyłania się wyraźny obraz wahań w sprawie uznania piramid za budowle

${ }^{91}$ Słowacki 1871.

${ }^{92}$ Widok 1871.

${ }^{93}$ Kołłątaj 1972.

${ }^{94}$ Barthélemy d'Herbeloth de Molainville (1625-1695) był autorem cytowanego przez Hugona Kołłątaja czterotomowego dzieła Bibliothéque orientale ou dictionnaire universel contenant généralement tout ce qui regarde la connaisance des peuples de I'Orient, ukazującego się w La Haye w latach 1777-1782. W wydaniu z 1776 r., do którego dotarłem hasło Gian \& Gian Ben Gian znajduje się na s. 368.

${ }^{95}$ Antoni Iwo Goguet (1716-1758), francuski filozof, historyk. Próba ustalenia tytułu jego artykułu zakończyła niepowodzeniem.

${ }^{96}$ Kołłątaj 1972, s. 783.

${ }^{97}$ Grabowski 1822 , s. $99,100$.

${ }^{98}$ Grabowski 1822 , s. 102. 
grobowe. Wynikać to może $\mathrm{z}$ różnych powodów. Jednym z nich z całą pewnością była szkolna lektura przede wszystkim Pliniusza Starszego, znakomitego rzymskiego „encyklopedysty”, jednakże bardzo niechętnego piramidom. Drugim źródłem wiedzy był zapewne Herodot. Wydaje się też, że chętnie sięgano po Diodora Sycylijskiego. Wyniesiona ze szkoły wiedza, oparta aż do lat 70. XIX w. właśnie na autorach antycznych, także kazała widzieć w Egipcie wysoką, idealną cywilizację, w której nie było miejsca na marnotrawienie sił narodu. $Z$ punktu widzenia oświeconego Europejczyka wznoszenie tak potężnej budowli wielkim nakładem sił i środków na grobowiec pojedynczego człowieka, choćby najznaczniejszego - byłoby jednak marnotrawstwem i bezsensem To przekonanie zapewne rzutowało na ów brak zdecydowania - za wszelką cenę poszukiwano ukrytego, racjonalnego sensu, zgodnego z ówczesną mentalnością. Także na próby datowania piramid rzutowała wyraźnie starożytna teoria wędrówki cywilizacji do Egiptu od południa (krainy długowiecznych), zasygnalizowana przez Homera, a tak wyraźnie wyartykułowana przez Herodota ${ }^{99}$.

Przedstawione w skrócie dzieje naukowych wyjaśnień fenomenu piramidy pozwalają na orientację w poziomie wiedzy przed odkryciami J.-F. Champolliona i narodzinami nowej gałęzi nauki - egiptologii. Pokazano również, że w świadomości wielu ludzi owe starodawne poglądy funkcjonowały jeszcze w początku XX w., o czym świadczą rozważania księdza Jakuba Górki. Musimy wszakże pamiętać, że w czasach, gdy zaprezentowane powyżej teorie powstawały, wiedza ich autorów ograniczała się wyłącznie do opisów pisarzy antycznych i ,turystów” wyprawiających się nad Nil, by podziwiać zabytki starożytnej cywilizacji; przede wszystkim nie korzystano z oryginalnych egipskich źródeł pisanych. Tylko nieliczni Polacy w tym czasie zainteresowali się bliżej wykopaliskami i zabytkami tej starożytnej cywilizacji ${ }^{100}$. Jednakże większość przybywających z ziem polskich do Egiptu, swą wiedzę o nim czerpała z ówczesnych przewodników.

Wiele z przedstawionych wyżej teorii okazało się manowcami nauki, jednak należy podejść do nich z szacunkiem, gdyż prezentowały ówczesny stan wiedzy. Były też zupełnie czymś innym niż rozwijająca się równocześnie $\mathrm{z}$ egiptologią piramidologia, która ignorując bieżący stan badań, opartych na źródłach materialnych i pisanych, zastępując wiedzę fantazją autorów, funkcjonuje nawet poza wszelkimi bezdrożami nauki, choć próbuje do miana nauki aspirować. Tymczasem można ją wprawdzie określić jako literaturę, ale nie zawsze piękną, o klarowności wywodu nie wspominając.

${ }^{99}$ Teza o zasiedleniu doliny Nilu od południa, czyli starszeństwa Teb nad Memfis, została oparta przede wszystkim na informacji Diodora Sycylijskiego (I, 50 i III, 2-3), a także na wcześniejszych wzmiankach znalezionych u Ajschylosa (Błagalnice 284-286) i Herodota (III, 17-26; VII, 69-70). Jeszcze w XIX w. pojawia się w wielu podręcznikach (np. Rottek 1842, s. 91-82; Levi-Alvares 1851, s. 21). Zdaniem Izydora Kacnelsona (1970, s. 163) początku tego poglądu, pojawiającego się już u autorów antycznych, należy poszukiwać u Homera w jego informacji o długowieczności i szczęśliwości plemion żyjących daleko na południu.

${ }^{100}$ Jako przykład może posłużyć osoba Józefa Kościelskiego z Miłosławia, autora szeregu artykułów poświęconych starożytnemu Egiptowi, jakie ukazywały się w ówczesnych pismach codziennych i naukowych przez kilka lat po jego pobycie w Egipcie (zob. Kościelski 2007; Kaczmarek 1997), czy Łukasza Dobrzańskiego (zob. Śliwa 1974a, b; 1977). 


\section{BIBLIOGRAFIA}

Abdel-Kader S.

1991 Les Obélisques Égypties histoire et archéologie, Le Caire (Supplément aux Annales du Service des Antiquités de l'Égypte Cahier No. 26).

Alexandrowicz S

1976 Peregrynacja do Ziemi Świętej księcia Radziwiłfa Sierotki. Czas powstania rękopisu, „Ars Historica", Poznań, s. 585-595.

Beckerath J. von

1997 Chronologie des pharaonischen Ägypten. Die Zeitbestimmung der ägyptischen Geschichte von der Vorzeit bis 332 v. Chr., Mainz am Rhein.

Bielicki M.

1966 Zapomniany świat Sumerów, Warszawa.

Bochnacki A.

1994 O piramidach inaczej, Gdańsk.

Boratini T. L.

1675 Misura universale, Wilno.

1897 Misura universale, Kraków.

Borzęcki H.

1776 Zbiór historii egipskiej i kartagińskiejz francuzkiego na polski język przełożony, Grodno.

Braun J.

1971 Stosunki etniczne starożytnej Mezopotamii, (w:) Mezopotamia, red. J. Braun, Warszawa.

Chmielowski B.

1754 Nowe Ateny albo Akademia wszelkiey scyencyi petna, na rozne tytuly iak na Classes podzielona,

Mądrym dla memoryahu, Idiotom dla nauki, Politykom dla praktyki, Melancholikom dla rozrywki erygowana, t. 3, Lwów.

Chrościcki J. A.

1974 Pompa funebris. Z dziejów kultury staropolskiej, Warszawa.

Černý J.

1976 Coptic Etymological Dictionary, Cambridge.

Donadoni S.

1990 Egypt over the centuries, (w:) S. Donadoni, S. Curto, A. M. Donadoni Roveri, Egypt from myth to Egyptology, Milano, s. 11-103.

Drohojowski J.

1812 Pielgrzymka X....Reformata Do Ziemi Świętey, Egiptu, niektórych wschodnich i południowych kraiów odbyta w Roku 1788, 89, 90 i 91, pobożno-ciekawey publiczności ofiarowana, Kraków.

Edwards I. E. S.

1995 Piramidy Egiptu, Warszawa.

Fischer von Erlach J. B.

1721 Entwurff einer Historischen Architectur: in Abbildung unterschiedener berühmten Gebäude des Alterthums und fremder Völcker; umb aus den Geschicht-büchern, Gedächtnüß-müntzen, Ruinen, und eingeholten wahrhafften Abrißen, vor Augen zu stellen, Leipzig.

Górka J

1913 Podróż do Ziemi Św. i Egiptu, Kraków.

Graefe E.

1911 Das Pyramidenkapitel in Al-Makrizi’s „Hitat“ nach zwei Berliner und zwei Münchner Handschriften unter Berücksichtigung der Bulaker Druckausgabe hrsg. und übersetzt von ..., Leipzig (Leipziger semitistische Studien; 5, H. 5). 
Grabowski A.

1822 Cuda i osobliwości Natury i Sztuki w różnych znayduiących się kraiach, z naynowszych $i$ nayciekawszych podróży do wszystkich części świata zebrane, z wiadomościami o niektórych celnieyszych starożytności zabytkach z kopersztychami illuminowane, Kraków.

Greaves J.

1646 Pyramidographia: or a description of the Pyramids in Aegypt, London.

Herbelot M. B.

1776 Bibliotheque Orientale ou dictionnaire universel, contenant ce qui regarde la connoissance des Peuples de l'Orient leurs histories et traditions Véritables ou fabuleuses, leurs religions, sects et politique, les Gouvernement, Loix, Coutumes, Mæurs, Guerres, \& les Révolutions de leurs Empires; Leurs sciences et leurs arts, Leurs Théologie, Mythologie, Magie, Phisique, Morale, Médicine, Mathématiques, Histoire naturelle, Chronologie, Géographie, Obesrvations Asronomiques, Grammaire, et Réthorique; Les vies et actions Remarquables et de tous leurs Saints, Docteurs, Philosophes, Historiens, Poëtes, Capitaines, \& de tous ceux qui se sont rendus illustres parmi eux, par leur Vertu, ou par leur Savoir; Des Jugements critiques, et des extraits de tous leurs ouvrages, De leurs Traités, Traductions, Commentaires, Abrégés, Recueils de Fables, de Sentences, de Maximes, de Proverbes, de Contes, de bon mots, \& de tous leurs Livres écrits en Arabe, en Persian, ou en Turc, sur toutes sortes de Sciences, d'Arts, \& de Professions, par... Maesticht.

Herwart von Hohenburg J. G.

1623 Admiranda ethnicæ theologix mysteria propalata: Vbi lapidem magnetem antiqvissimis passim nationibvs pro deo cvltvm: et artem qva nauigationes magneticx per vniuersum orbem instituerentur, à veterum sacerdotibus, sub inuolucris deorum, dearúmque et aliarum perinde fabularum cortice, summo studio occultatam esse nouiter commonstratur. Accessit, exacta temporum ratio, aduersis incredibiles chronologix vulgaris errores, opus diu desideratum, Monachii.

Hornung E.

1999 Das esoterische Ägypten. Das geheime Wissen der Ägypter und sein Einfluß auf das Abendland, München.

Jablonski P. E.

1752 Prolegomena, (w:) Pantheon Aegyptioyum sive de Diis eorum commentarius cum Prolegomenis de religione et Theologia Aegyptiorum, Francofurti ad Viadrum.

Jonston J.

1634 Naturae Constantia, Amstelodami.

1657 An History of the Constancy of Nature by John Jonston of Poland, London.

1960 O stałości natury, tłum. wyd. M. Stokowska, Kraków (Biblioteka Klasyków Filozofii).

Kacnelson I.

1970 Напата и Мероэ - древние царства Судана, Москва.

Kaczmarek H.

1997 Egyptian Travel of Józef Kościelski, Warsaw Egyptological Studies, I: Essays in honour of Prof. Dr. Jadwiga Lipińska, Warszawa, s. 249-257.

Kołłątaj H.

1972 Rozbiór krytyczny zasad historii początkowej wszystkich ludów, opr. i wstęp H. Hinz, Warszawa.

Kortens J.

1743 Reise nach dem welland Gelobten Nun aber seit siebenzehn hundert Jahren unter dem Fluche liegenden Lande, Wie auch nach Egypten, dem Berg Libanon, Syrien und Mesopotamien von ihn selbst aufrichtig beschreiben und bey diese zweyten Auflage mit zwei Supplementen vermehret, Halle.

Kościelski J.

2007 Szkice egipskie. Wrażenia z podróży. Studia i Materiały, opr. H. Kaczmarek, Poznań. 
Krasicki I.

1781 Zbiór potrzebnych wiadomości porządkiem alfabetycznym ułożonych, Warszawa.

Kraszewski J. I.

1860 Podróże i poselstwa polskie do Turcyi, a mianowicie: Podróż E. Otwinowskiego 1557, Jędrzeja Taranowskiego komornika J.K.M. 1569, i Poselstwo Piotra Zborowskiego. 1568 przygotowane do druku z rękopismu przez... Wydanie Kazimierza Józefa Turowskiego, Kraków.

Lee I. L.

2007 Okres hellenistyczny. Aleksander Wielki. Narodziny i upadek dynastii hasmonejskiej, (w:) Starożytny Izrael od Abrahama do zburzenia świątyni jerozolimskiej przez Rzymian, red. H. Shanks, Warszawa.

Leszczyński R.

1998 Poselstwo Rafała Leszczyńskiego do Turcji w 1700 roku. Diariusze i inne materiały, opr. I. Czamańska przy współpracy D. Zydorek, Leszno.

Levi-Alvares D.

1851 Obraz historyi powszechney skreślony podhug nowej zupelnie metody ułatwiayącej wykład i naukę głównych wypadków od stworzenia świata do naszych czasów przez... wedle 22 go wydania przełożył z francuskiego Henryk K. Liebleind, Część I: Dzieje starożytne, Warszawa.

Łubieński W.

1740 Świat we wszystkich swoich częściach większych y mnieyszych, to iest: w Europie, Azyi, Afryce y Ameryce, w monarchiach, krolestwach, xięstwach, prowincyach, wyspach y miastach, geograficznie, chronologicznie y historycznie okryślony. Opisaniem religii, rządów, rewolucyi, praw. zwyczaiów, skarbów, ciekawości y granic każdego kraiu z autorów Francuskich, Włoskich, Niemieckich y Polskich zebranym przyozdobiony, przez... Wrocław.

Maciejowski K.

1871 Siedem cudów świata, „Przyjaciel Dzieci. Pismo tygodniowe nauce i rozrywce młodzieży poświęcone z dodatkiem dla małych Dzieci”, r. XI, nr 3 z 9/21 I, s. 23-24.

Małecki A.

1851 Prelekcye o Filologii klasycznej i jej Encyklopedyi miane w półroczu letniem r. 1850, Kraków.

Mejer K.

1867 Piramidy Egipskie, „Opiekun Domowy. Pismo tygodniowe obrazkowe”, r. III, nr z 12 (24) VII, s. 233-234.

Miaskowski W.

1985 Wielka legacja Wojciecha Miaskowskiego do Turcji w 1640 r., opr. A. Przyboś, Warszawa-Kraków.

Moszyński A.

1970 Dziennik podróży do Francji i Włoch ... architekta JKM Stanisława Augusta Poniatowskiego 1784-86, opr. B. Zboińska-Daszyńska, Kraków.

Otwinowski E.

1860 Wypisanie drogi tureckiej, gdym tam z posłem wielkim wielmożnym panem Andrzejem Bzickim, kasztelanem chelmskim, od króla Zygmunta posłanym roku pańskiego 1557 jeździł, (w:) Józef Ignacy Kraszewski: Podróże i poselstwa polskie do Turcyi, a mianowicie: Podróż E. Otwinowskiego 1557, Jędrzeja Taranowskiego komornika J.K.M. 1569, i Poselstwo Piotra Zborowskiego. 1568 przygotowane do druku z rękopismu przez... Wydanie Kazimierza Józefa Turowskiego, Kraków.

Pauw C. de

1774 Recherches philosophiques sur les Égyptiens et les Chinois, Pour servir de suite aux recherches philosophiques sur les Americans, Geneve.

Pawlicki S.

1877 Tajemnice wielkiej piramidy, „Kronika Rodzinna. Pismo dwutygodniowe”, seria II, t. 5, s. 145-147.

Pelczar J.

1875 Ziemia Święta i Islam czyli szkice z pielgrzymki do Ziemi Świętej, którą w roku 1872 odbył i opisał $k s . d r . .$. t. I: Ziemia Święta; t. II: Islam, Lwów. 
Perry $\mathrm{Ch}$.

1743 A View of the Levant: particularly of Constantinople, Syria, Egypt, and Greece. In which their antiquities, government, politics, maxims, manners, and customs,(with many other Circumstances and Contingencies) are attempted to be Described and Treated on, London.

Potocki J.

1959 Podróże, wyd. L. Kukulski, Warszawa.

Radziwiłł M. K.

1601 Jerosolymitana Peregrinatio... Nicolai Christophori Radzivili Ducis Olicae et Niesvilii Palatini Vilnensis Militis Jerosolymitani etc. Primum a Thoma Tretero Custode Varmiensi E Polono sermone in latinum translata, Bunsbergae.

1603 Juengst geschehene Hierosolimitanische Reise, Moguncja.

1607 Peregrinacia abo pielgrzymowania do Ziemie świetey przez Tomasza Tretera... językiem łacińskim napisane a przez X Andrzeja Wargockiego .. na polski przełożona, Kraków.

1787 [Радивил] Путишестие ко святым местам и в Египет; Петерсбург.

1879 Радивил: Похождениев Эемлю Святую княэя Радивила Сиротки 1582-1584, Спб.

1925 Peregrynacja do Ziemi świętej (1582-1584), wyd. J. Czubek, Kraków („Archiwum do dziejów Literatury i Oświaty w Polsce", t. XV, cz. 2).

1962 Podróż do Ziemi świętej Syrii i Egiptu 1582-1584, opr. L. Kukulski, Warszawa.

1990 Kelioné i Jeruzalę. Iš lotynų vertč Ona Matusevičiūté, Vilnius.

1994 Пэрэгрынацыя або Паломніцтва Ясна Асветленага Княэя Ягомосці Мікалая Крыштофа Радэівіла ў Святую Эямлю, w: Кніга жыцій і хаджэнняў, Минск, s. 165-447.

Rollin $\mathrm{K}$.

1743 Na większa chwałę Boga a synom oyczyzny na pożytek Dziejopis starożytny Egipcyanów, Kartainców, Assyryiczyków, Babilońców, Medów, Persów, Macedończyków y Greków przez ... Rektora Szkół Paryzkich, Nauczyciela wymowy w Kollegium Królewskim, y Kollegę Akademii Królewskiey napisów, y wyzwolonych nauk, francuskim ięzykiem napisany, A od Józefa Alexandra xiążęcia $z$ Prussów na Jabłonowie y Lacowcach, hrabi na Lisiance $i$ Zawałowie, L B na Podhorcach Jabłonowskiego, Buskiego, Korsuńskiego, Wołyńskiego, Zagośćkiego, Onyxteńskiego, Dzwinogrodzkiego starostę, Lawaryskiego, Rakanciskiego dzierżawcę y rosmistrza woysk Koronnych, na Oyczystą mową wyłożony, t. I, Lublin.

Romerowie J. i E.

1997 Siedem cudów świata. Historia nowoczesnej wyobraźni, Warszawa.

Rottek K.

1842 Obraz historyi powszechnej od najdawnieszych do najnowszych czasów. Dzieło z niemieckiego przerobione przez Leona Rogalskiego, Warszawa.

Sandys $\mathrm{G}$.

1615 A Relation of a Journal begun A. Dom. 1610. Foure Books. Containing a description of the Turkish Empire, of Aegypt, of the Holy Land, of the Remote Parts of Italy and Ilands adjoyning, London.

Sas-Zubrzycki J.

1910 Styl nadwiślański jako odcień sztuki średniowiecznej w Polsce, Kraków.

1928 Znaczenie piramid egipskich, Lwów.

Schroeck J. M.

1813 Historya powszechna przez ... z niemieckiego ięzyka na polski przez X Pawła Kotowskiego S.P. przethumaczona potrzebnemi dodatkami pomnożona, $i$ do roku 1812 doprowadzona, WilnoWarszawa.

Słowacki E.

1824 Teorya smaku w dziełach sztuk pięknych, (w:) Dzieła z pozostałych rękopismów ogłoszone, t. I, Wilno. 
Słowacki J.

1871 Odwiedziny piramid, „Przyjaciel Dzieci. Pismo tygodniowe nauce i rozrywce młodzieży poświęcone z dodatkiem dla małych Dzieci", r. XI, nr 11 z 6/18 III, s. 101-102.

Sołtyk M.

1784 Encyklopedya wiadomości elemantarnych czyli pierwsze rysy $i$ wyobrażenia nauk $i$ kunsztów dla użytku młodzieży przez..., cz. 1-2, Kraków.

Stadelmann R.

1997 Die ägyptischen Pyramiden. Vom Ziegelbau zum Weltwunder, Mainz a.Rhein.

Starowolski S.

1858 Dwór cesarza tureckiego i rezydencya jego w Konstantynopolu, Kraków.

Steffen W.

1969 Sylwetki filologów wielkopolskich. Antoni Małecki, „Meander”, r. XXIV, s. 416-423.

Stryjkowski M.

1978 O początkach, wywodach, dzielnościach, sprawach rycerskich $i$ domowych sławnego narodu litewskiego, żmojdzkiego i ruskiego, przedtym nigdy od żadnego ani kuszone ani opisane $z$ natchnienia Bożego, a uprzejmie pilnego doświadczenia, Warszawa.

Szybiński D.

1772 Krótka wiadomość o znakomitych w świecie monarchiach, starodawnych krolestwach, rzeczachpospolitych, tudzież o cesarzach państwa rzymskiego i jego podziale, upadku wzmocnieniu na Zachodzie, powstanie natomiast tureckiego na Wschodzie, y rewolucyach w nich zachodzących do naszych czasów, Warszawa.

Śliwa J.

1974a Lukasz Dobrzański (1864-1909) i jego zainteresowania archeologią Egiptu, „Filomata” 276, s. $322-328$

1974b Eukasz Dobrzański jako jeden z prekursorów polskich zainteresowań starożytnym Egiptem, „Meander", r. XXIX, s. 91-96.

1977 Lukasz Dobrzański and his excavations in Egypt, 1895, „Schriften zur Geschichte und Kultur des Alten Orients", Bd. 13: Ägypten und Kush, s. 397-400.

Terrasson J.

1731 Séthos. Histoire ou vie tirée des monuments, anecdotes de l'ancienne Egypte. Ouvrage dans lequel on trouve la description des Initiations aux Mysteres Egyptiennes, traduit d'un manuscript Grec. Paris.

Tietze Ch.

1999 Die Pyramide. Geschichte - Entdeckung - Faszination, Weimar-Berlin.

Tomkiewicz S

1888 Sprawozdania z posiedzeń Komisyi Historyi Sztuki za czas od 1 stycznia do 31 marca 1888 zestawione przez sekretarza Komisyi Dra ..., „Sprawozdania Komisyi do badania historyi sztuki w Polsce", t. III.

Tuczyński F. X.

1878 Cuda świata, „Oświata. Tygodnik katolicko-narodowy dla stanu średniego”, r. III, nr 119 z dnia 12 IV, s. 998-999 i nr 120, z 19 IV, s. 1006-1007.

Wörterbuch

1971 Wörterbuch der aegyptischen Sprache, Hrsg. von A. Erman und H. Grapow, Berlin.

Wężyk W.

1842 Podróże po starożytnym świecie... w dwóch częściach. Egipt, cz. I: Dzieje, cz. II: Obrazy, Warszawa.

Widok

1871 Widok piramid w Egipcie (wzięty z miejsca gdzie dawniej stało miasto Memfis), r. XI, nr 28 z dnia 3/16 lipca, s. 308 , il. s. 305 
Witte S. S.

1789 Ueber den Ursprung der Pyramiden in Egypten und der Ruinen von Persopolis, ein neuer Versuch, Leipzig.

Zakrzewski E.

1850 Historya powszechna, t. I: Świat przedchrześcijański, Poznań.

Zinkow L.

2006 Nad Wisłą, nad Nilem ... Starożytny Egipt w piśmiennictwie polskim (do roku 1914), Kraków.

2009 Imhotep i pawie pióra. Z dziejów inspiracji egipskich $w$ architekturze polskiej, Kraków.

Złotnicki A.

1891 Egipt, „Świat. Dwutygodnik Ilustrowany”, r. IV, s. 533-536, 550-554, 571-576.

\section{THE EGYPTIAN PYRAMIDS - PHARAOH'S TOMBS OR JOSEPH'S GRANARIES}

\section{S u m m a ry}

Pyramids, erected by the ancient Egyptians, have generated interest and admiration already for the ancient societies. This admiration has been well manifested in imitation of the pyramids in the ancient sepulchral architecture of Meroe, Syria and Europe. In the sixteenth century one would found also in Poland different buildings reminiscent of the pyramids. At the same time, there were reflections on the symbolic and practical purpose of the pyramids of ancient Egypt. Theoretical reflections on the pyramids, with significant contribution of Poles, went in two directions. One comprised „iconology” - searching for hidden, symbolic meanings of the pyramids; the second represented an attempt to explain their real purpose. However, despite the fact that the purpose of the pyramids has not always been accurately explained, the efforts made in this field are worthy of attention and further research.

Translated by Ewa Loba-Bronowicka 